\title{
ASSESSMENT OF SOIL COMPACTION AND SHEAR STRENGTH OF THE SIDE DAM OF THE “MAZIARNIA” WATER RESERVOIR
}

\author{
Andrzej Gruchot ${ }^{\bowtie}$ \\ Department of Hydraulic Engineering and Geotechnics, University of Agriculture in Krakow, al. Adama Mickiewicza 24/28, \\ 30-059 Kraków
}

\begin{abstract}
Aim of study

The aim of the study was to assess soil compaction of the side body of the "B" earth dam in the "Maziarnia" water reservoir in Wilcza Wola in the Podkarpackie Voivodeship by using a conical and a vane probe of a dynamic probing light. Shear strength parameters of soils embedded in the dam's body were also determined, i.e. undrained shear strength basing on field tests and the angle of internal friction and cohesion in a direct shear apparatus.
\end{abstract}

\section{Materials and methods}

Field tests included the determination of bulk density of soil and sounding with a dynamic probing light together with identifying the undrained shear strength in four sections located on the downstream slope over a section of about $300 \mathrm{~m}$. Grain composition and compaction parameters were measured in laboratory tests in the Proctor apparatus. Shear strength parameters were also determined, i.e. the angle of internal friction and cohesion in a direct shear apparatus on samples without and with saturation during consolidation and shearing.

\section{Results and conclusions}

The analysis of obtained results indicates that the values of degree of compaction and compaction index - estimated on the basis of their correlations - differed significantly depending on the probe vane. It was found that for the most part the soils making the side dam's body were characterized by low values of compaction index. However, the stability of the entire object was assessed as high due to high values of shear strength parameters from the vane probe test and the direct shear apparatus. Analysis of the results of shear strength tests in field and laboratory conditions showed no clear correlations between the tested parameters.

Keywords: cohesion, angle of internal friction, dynamic probing light, undrained shear strength

\section{INTRODUCTION}

Geotechnical control of compaction of the earth dam's body after a long period of operation can be complicated and expensive. The scope of most of research includes static sounding with the CPTU probes or dy- namic sounding with a conical (SD) or vane (FVT) or a combination of both (SLVT). Limiting the phenomena of filtration through the structure and its subsoil is required for proper operation of the dam. This issue is most often implemented through a control of filtration water levels in piezometers and filtration calculations

凶e-mail: andrzej.gruchot@urk.edu.pl 
using model tests and numerical methods (Baran et al., 2016; Gruchot et al., 2019).

The safety of earth hydrotechnical structures, i.e. dams or embankments, requires checking the stability of the whole structure and its components e.g. slopes. According to Eurocode 7, stability testing in Poland is run in compliance with the DA3 design approach (PN-EN 1997-1: 2008) and requires information from calculating the parameters of shear strength of soils. To estimate shear strength parameters based on the results of field tests, mainly soundings, correlations between these parameters and the number of impacts of the beater or cone resistance, as well as the type of soil, have to be measured. However, such assumptions affect the accuracy of their estimation and thus the quality of engineering calculations. It should be pointed out that, despite the increasingly accurate field test methods, the results do not always reflect actual soil conditions (Godlewski, 2013; Hawrysz and Stróżyk, 2015; Zydroń, 2016). For this reason, further laboratory tests on samples with intact structure or formed to a specific bulk density are recommended, allowing to determine with due accuracy the geotechnical parameters required in calculations, including the angle of internal friction and cohesion.

The aim of the study was to assess soil compaction of the side body of the "B" earth dam in the "Maziarnia" water reservoir in Wilcza Wola in the Podkarpackie Voivodeship by using a conical and a vane of a dynamic probing light. The obtained compaction results were related to the Proctor method. Additionally, shear strength parameters of soils embedded in the dam's body were also determined, i.e. undrained shear strength, though on field tests and the angle of internal friction and cohesion in a direct shear apparatus.

\section{LOCATION AND CHARACTERISTICS OF THE RESERVOIR}

The dam of the "Maziarnia" water reservoir in Wilcza Wola is located in $56.1 \mathrm{~km}$ of the Łęg River, the rightbank tributary of the Vistula, closing the catchment area of $233.0 \mathrm{~km}^{2}$. The Łęg River catchment belongs to the Kolbuszowski Plateau and the Rozwadowska Plain, situated within the Sandomierz Basin (Tar- nawski and Michalec, 2006). The reservoir was commissioned in 1989, and its task is to cover the needs of local waterworks, sprinkler irrigation and pond farms. The capacity of the reservoir is 3.86 million $\mathrm{m}^{3}$, with an embankment area of 160 ha with a normal damming ordinate $187.50 \mathrm{~m}$ a.s.l. and average depth $2.45 \mathrm{~m}$. The resulting reservoir is a trough type reservoir (Instruction, 2011; Tarnawski and Michalec, 2006), and its axis length is $6.5 \mathrm{~km}$. The spillway section is a weir of composite construction built into the central part of the front dam's body.

The length of the front dam is $420 \mathrm{~m}$, and its crown ordinate is $190.40 \mathrm{~m}$ a.s.1. with a crown width of $6.0 \mathrm{~m}$. The inclination of the slopes is $1: 2.5$, and they are protected from the downstream side by sod, while from the upstream side - by concrete slabs with a thickness of $15 \mathrm{~cm}$. The total length of all side dams ("A", "B" and "C") totals $3720 \mathrm{~m}$, and the width of their crowns is $3.0 \mathrm{~m}$ on average. The upstream slope of the " $\mathrm{B}$ " side dam protected with concrete slabs has a gradient of $1: 3$, and the downstream side covered by sod has $1: 2.5$ (see: Fig. 1).

\section{SCOPE AND METHODS OF TESTS}

Field tests included measuring the bulk density of soil using the ring method and sounding with a dynamic probing light with a conical and vane probe (see: Table 1). The tests were carried out in four cross-sections located along the "B" side dam (see: Fig. 2) on the downstream slope over a section of about $300 \mathrm{~m}$. Three test openings were made in each cross-section, covering the full height of the escarpment. Their aim was to determine moisture content and bulk density on two different levels and to take samples for laboratory tests.

Probing was carried out with a dynamic probing light (DPL) in all sections on the edge of the dam's crown on the downstream slope and at its subsoil. During the probing, the number of hits of a $10 \mathrm{~kg}$ beater was recorded per $10 \mathrm{~cm}$ of probe drive. Sounding points using both vanes were spaced about $0.5 \mathrm{~m}$ apart. The depths of sounding with a conical and vane were similar and amounted to $3.0 \mathrm{~m}$ near the crown edge of the dam and ranged from $2.7 \mathrm{~m}$ (P2 cross-section) to $6.0 \mathrm{~m}$ ( $\mathrm{P} 4$ cross-section) at the bed of the downstream slope. 


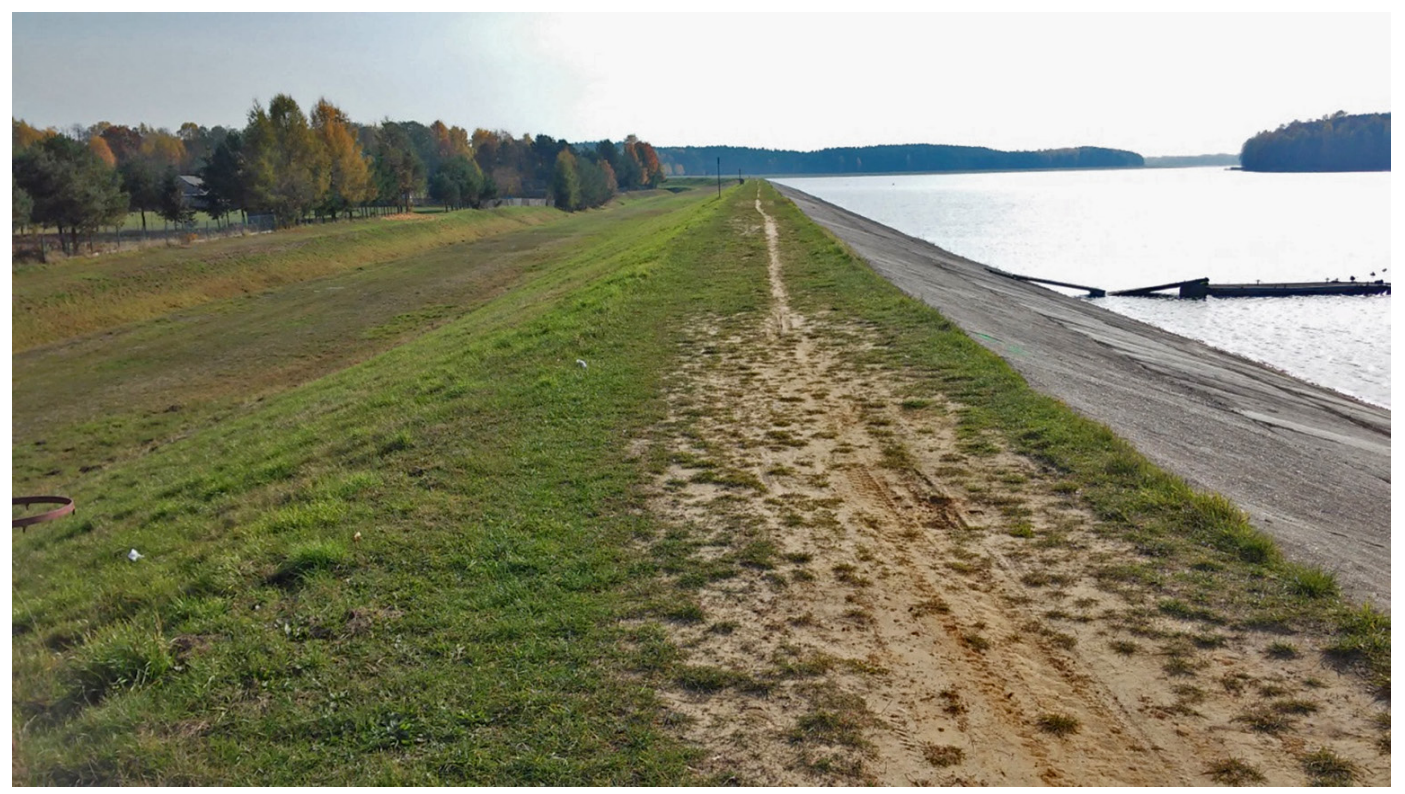

Fig. 1. View of the 'B' side dam (photo A. Gruchot)

Table 1. Characteristics of vanes used for dynamic probe light

\begin{tabular}{lll}
\hline & \multicolumn{2}{c}{ Probe } \\
\cline { 2 - 3 } & & Conical \\
\hline
\end{tabular}

Due to dominant sand formations with some overlayerings of cohesive soils, the state of compaction was treated as for non-cohesive soils, referring to the degree of compaction. The analysis was conducted separately for sounding with a conical and vane. The degree of compaction $\left(I_{D}\right)$ was calculated by the number of beater hits per $10 \mathrm{~cm}$ probe drive $\left(\mathrm{N}_{10}\right)$ from the equation (PN-B-04452: 2002):

$$
I_{D}=0.429 \cdot \log N_{10}+0.071[-]
$$

In order to determine the compaction index $\left(I_{S}\right)$ through sounding, the degree of compaction values obtained from probing with a conical vane were converted $\left(I_{D}\right)$ to the values of compaction index from the equation (Dąbska and Pisarczyk, 2016; PN-B- 04452: 2002):

$$
I_{S}=\frac{0.818}{0.958-0.174 \cdot I_{D}}
$$

or

$$
I_{S}=0.855+0.165 \cdot I_{D}
$$

While probing with a cross-shaped vane, undrained shear strength was measured at levels selected from 
the conical vane probing. When shearing soil, a rod with a torque wrench was spinning at a speed of $60^{\circ}$ per minute. Maximum and minimum values of probe torque $(M)$ were used for calculating undrained shear strength of soil $\left(\tau_{f u}\right)$ by the formula (PN-B-04452: 2002):

$$
\tau_{f u}=\frac{2 \cdot M}{\pi \cdot D^{2} \cdot\left(H+\frac{D}{3}\right)}[\mathrm{kPa}]
$$

given:

$M$ - torque at the moment of soil shearing, $[\mathrm{kNm}]$,

$D$ - diameter of the vane, $[\mathrm{m}]$,

$H$ - height of the vane, [m].

The scope of laboratory tests included the determination of grain size by sieve analysis, natural moisture content by the drying method at $105^{\circ} \mathrm{C}$, compactibility parameters and shear strength. Compactibility parameters were determined in a Proctor's apparatus, in a cylinder with a volume $1.0 \mathrm{dm}^{3}$ at a compaction energy of $0.59 \mathrm{~J} \cdot \mathrm{cm}^{-3}$ (PN-B-04481:1988). The obtained results were used to identify the compaction index $\left(I_{S}\right)$, according to the Proctor method:

$$
I_{S}=\frac{\rho_{d}}{\rho_{d s}}[-]
$$

given:

$\rho_{d}-$ dry density of solid particles, from field tests, $\left[\mathrm{g} \cdot \mathrm{cm}^{-3}\right]$,

$\rho_{\mathrm{ds}}-$ maximum dry density of solid particles, from tests by the Proctor apparatus, $\left[\mathrm{g} \cdot \mathrm{cm}^{-3}\right]$,

Shear strength parameters, i.e. the angle of internal friction and cohesion, were measured in a direct shear apparatus on samples with cross-sectional dimensions of $10 \times 10 \mathrm{~cm}$ and a height of $2.0 \mathrm{~cm}$. Test samples were formed directly in the apparatus at natural moisture content to obtain bulk density from field tests. After compaction, the samples were consolidated for $30 \mathrm{~min}$ and then sheared at the velocity

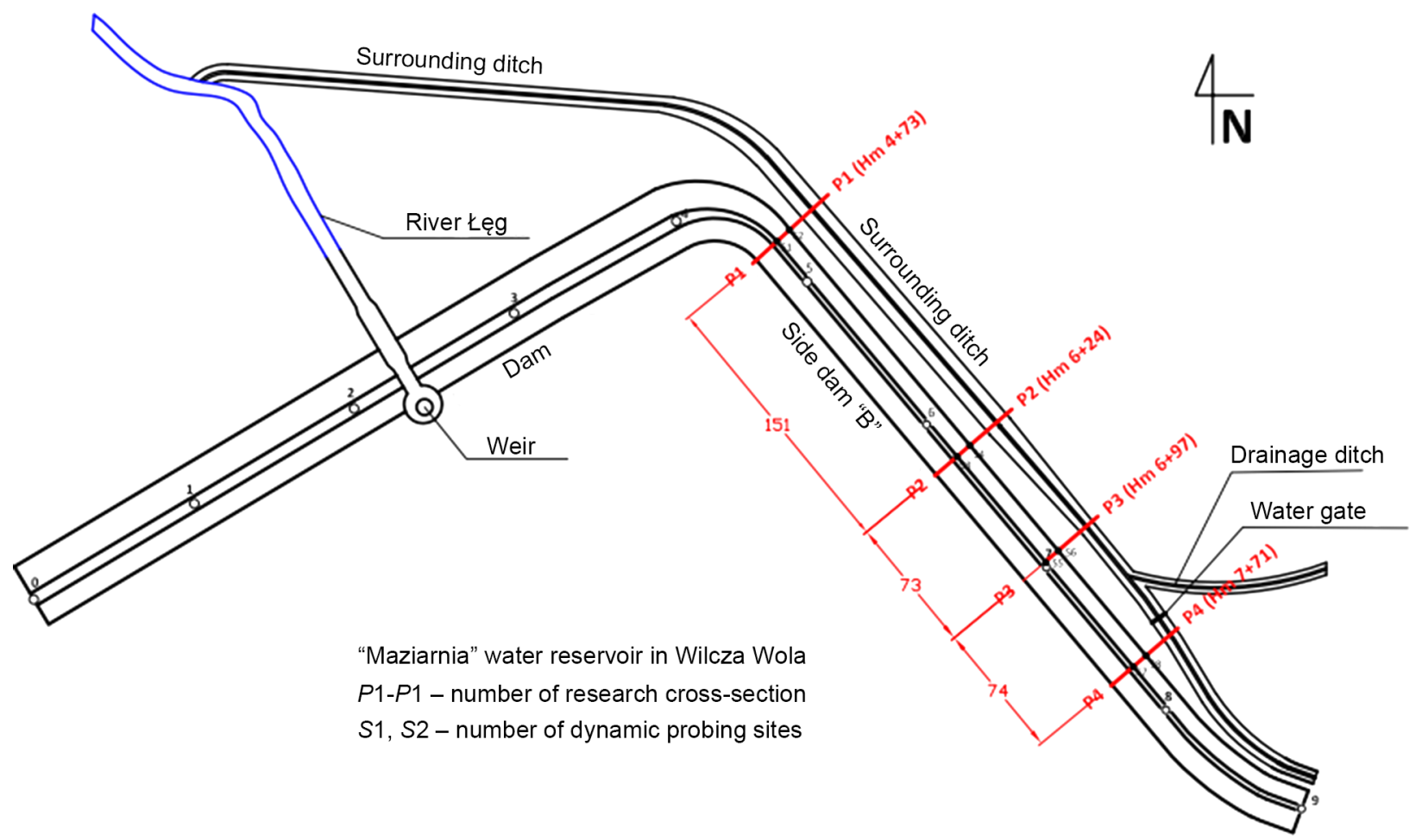

Fig. 2. Location of reaserch cross-sections on the 'B' side dam on the 'Maziarnia' water reservior in Wilcza Wola 
of $0.2 \mathrm{~mm} \mathrm{~min}^{-1}$ and at the following normal stresses: $50,100,200$ and $400 \mathrm{kPa}$, when the bottom part of box of the apparatus was moved. The shear criterion was the maximum value of the shear stress in the range of up to $20 \%$ of the horizontal deformation of the sample. In order to demonstrate the influence of moisture content, tests were carried out without and with water accumulation in samples under consolidation and shear.

\section{TEST RESULTS AND ANALYSIS}

\section{Geotechnical structure of the dam body}

Field and laboratory tests of soils collected from research excavations located on the downstream slope found that:

- in section P1 $(\mathrm{Hm} 4+73)$ to a depth of $1.5 \mathrm{~m}$ there were medium silty sands, up to 2.4 m medium sands and up to $3.4 \mathrm{~m}$ medium clay sands (see: Fig. 3). Soil moisture content ranged from 4 to $13 \%$, and bulk density from 1.7 to $2.1 \mathrm{~g} \cdot \mathrm{cm}^{-3}$. Maximum dry density of solid particles varied from
1.84 to $1.97 \mathrm{~g} \cdot \mathrm{cm}^{-3}$ at an optimum moisture content of 10.2 to $10.8 \%$ (see: Fig. 4 ).

- in the section P2 (Hm $6+24), 5.1 \mathrm{~m}$ in depth, there were medium sands with moisture content ranging from 7 to $17 \%$ and bulk density between 1.6 and $2.0 \mathrm{~g} \cdot \mathrm{cm}^{-3}$. Maximum dry density of solid particles of the sand varied from 1.83 to $1.87 \mathrm{~g} \cdot \mathrm{cm}^{-3}$ at an optimum moisture content of 10.2 to $11.0 \%$

- in the section P3 (Hm 6 + 97) up to $5.3 \mathrm{~m}$ in depth were medium clay sands and silty fine sands below $3.3 \mathrm{~m}$. Soil moisture content ranged from 9 to $15 \%$, and bulk density from 1.9 to $2.1 \mathrm{~g} \cdot \mathrm{cm}^{-3}$. Maximum dry density of solid particles varied from 1.78 to $1.94 \mathrm{~g} \cdot \mathrm{cm}^{-3}$ at an optimum moisture content of 10.0 to $16.2 \%$.

- in the section P4 $(\mathrm{Hm} 6+24)$, there were medium sands with moisture content ranging from 7 to $17 \%$ at depth of $5.1 \mathrm{~m}$ and bulk density between 1.64 and $1.84 \mathrm{~g} \cdot \mathrm{cm}^{-3}$. Maximum dry density of solid particles varied from 1.84 to $1.85 \mathrm{~g} \cdot \mathrm{cm}^{-3}$ at an optimum moisture content of 10.8 to $11.0 \%$.

FRACTIONS

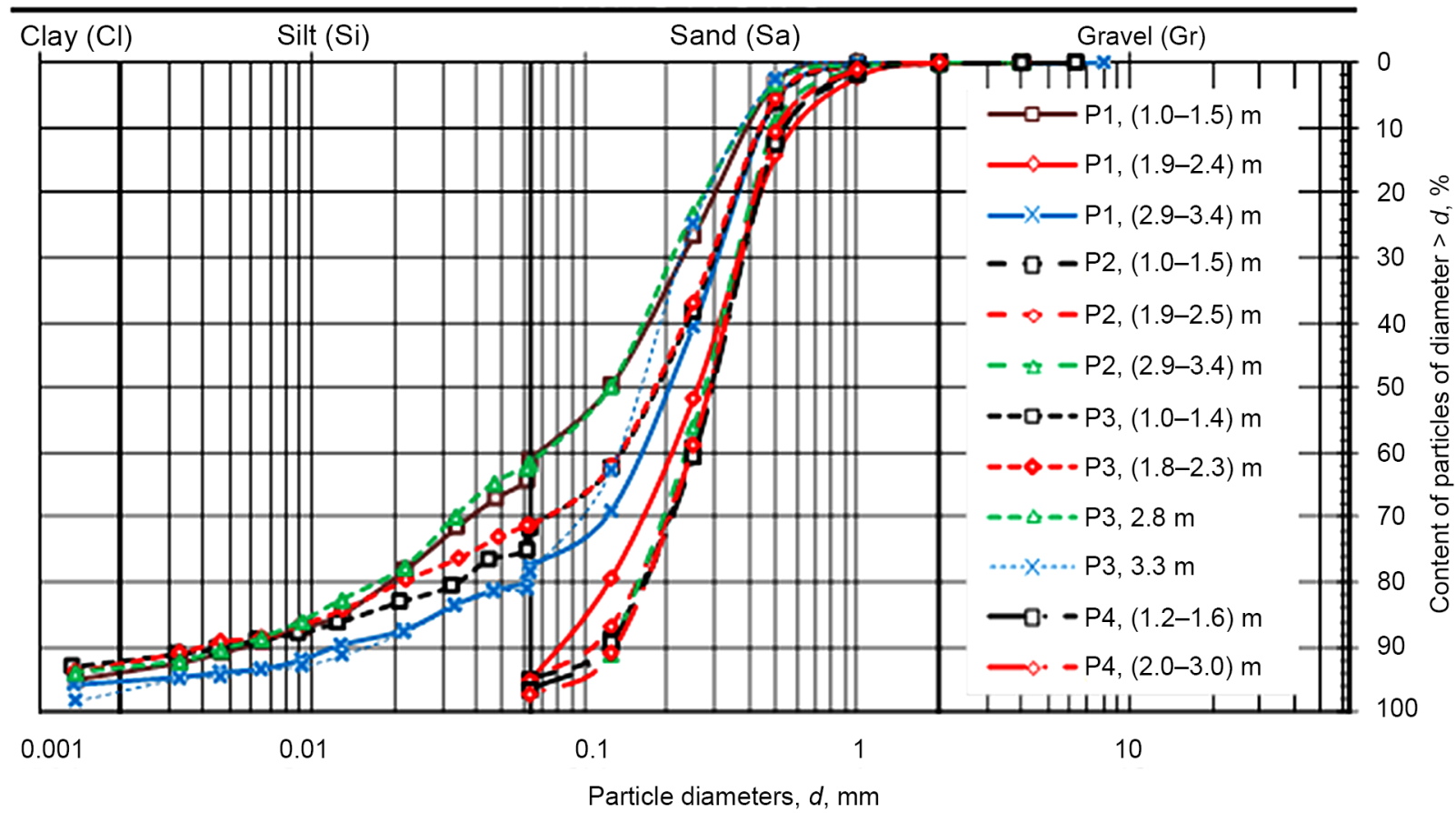

Fig. 3. Grain size distribution curves of soils from research excavations situated on downstream slope 

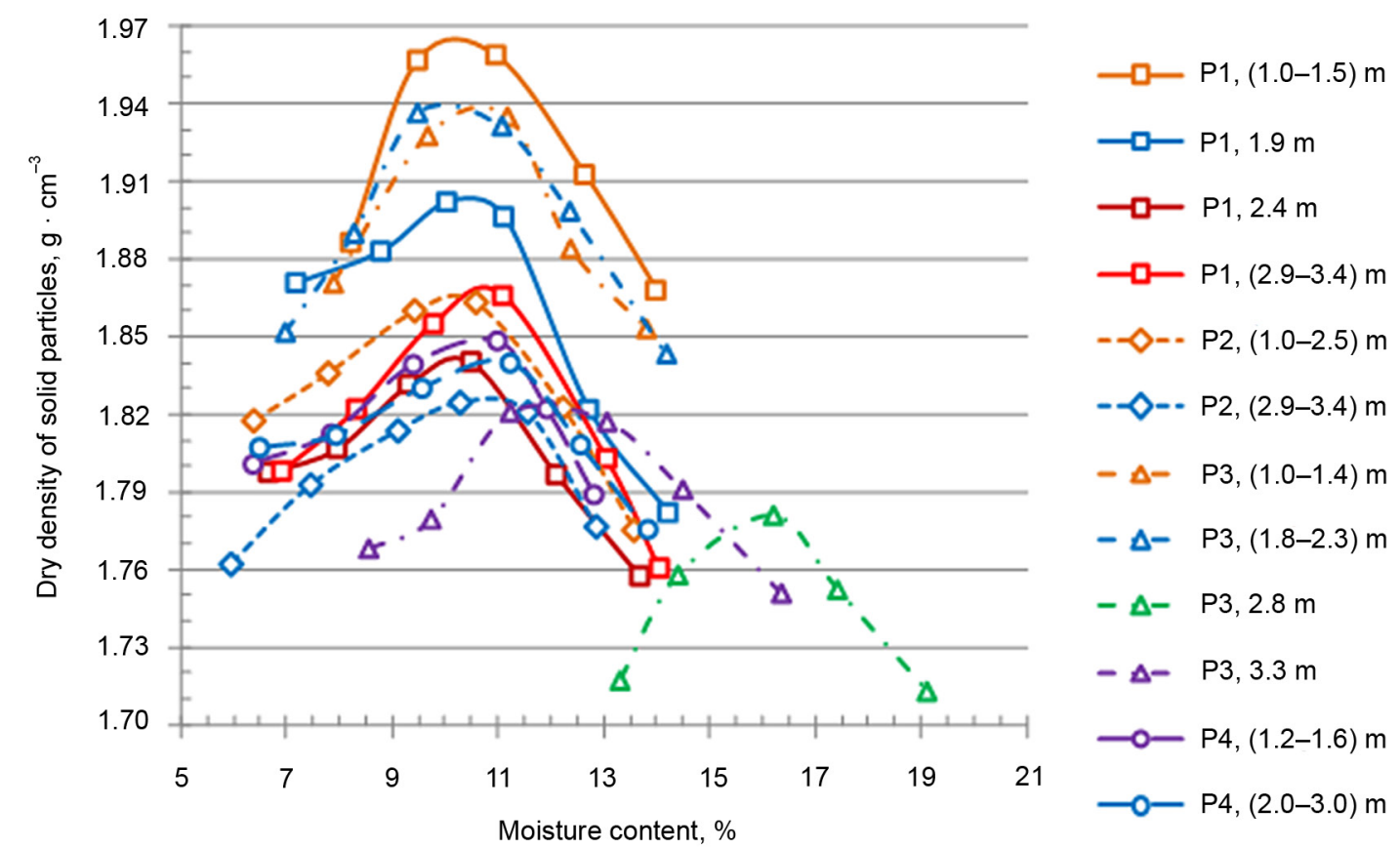

Fig. 4. Compactibility curves of soils from the dam body

\section{Degree of compaction}

Results obtained from the dynamic sounding with a conical and vane proved that medium-compacted (mcs), compact (cs) or very compacted (ves) soils occur in the dam's body (see: Figs. 5 and 6) (PN-EN ISO 14688-2 2006). Only in the surface zone in the $\mathrm{P} 1$ and P3 cross-sections during the soundings at the bed of the slope there were soils in a loose state (ls). Comparing the results of sounding with the both vanes, a similar state of soil compaction in the analysed cross-sections becomes clear. It should be noted, however, that the scope of differences in the values of the degree of compaction between both vanes was significant and ranged from 0.11 to 0.30 . As a result, at certain depths, depending on the probe vane, there were differences in the interpretation of the state of compaction of the dam's body.

Figure 6 shows cross-sections of compaction through the studied section of the side dam including both probe vanes. As indicated earlier, the analysis of both cross-sections showed similar changes in soil compaction in correspondence with depth. However, the thickness range of individual soil layers with a fixed compaction state differed between both vanes of the probe. Based on the analysis of the results of dynamic probing tests, it is difficult to unequivocally indicate the probe vane, which provided reliable estimation of the state of compaction. Higher values of the degree of compaction were obtained at some depths by probing with a conical vane, and at others with a vane. This confirms the possibility of using dynamic probing primarily to trace weak spots or homogeneity of compaction with a careful approach to identifying the degree of compaction. It is suggested to use a dynamic conical probe in sandy soils to control their compaction, and a cross-shaped probe only if necessary to determine undrained shear strength.

\section{Compaction index}

According to equation (2), the degree of compaction collected from sounding with a dynamic probe was converted into the compaction index. The obtained calculation results indicate that its range was quite large. For probing with a conical vane ranged from 0.90 to 1.03 and a cross-shaped vane from 0.87 to 1.03 . The resulting values of the compaction index 
Gruchot, A. (2019). Assessment of soil compaction and shear strength of the side dam of the "Maziarnia" Water reservoir. Acta Sci. Pol., Formatio Circumiectus, 18 (3), 133-147. DOI: http://dx.doi.org/10.15576/ASP.FC/2019.18.3.133

a) cross-section $\mathrm{P} 1$

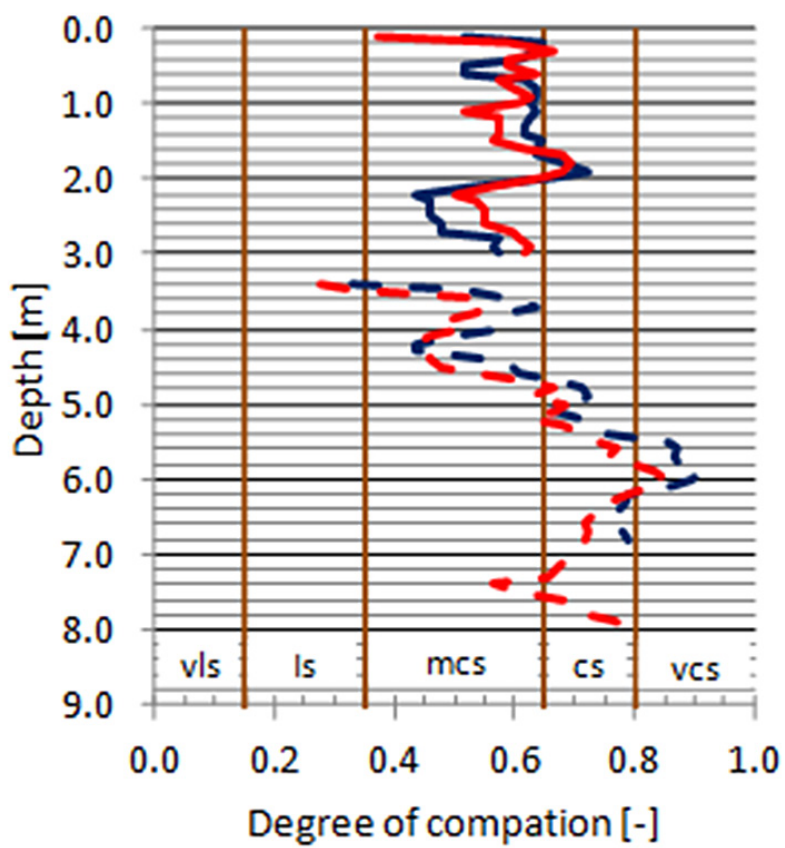

c) cross-section P3

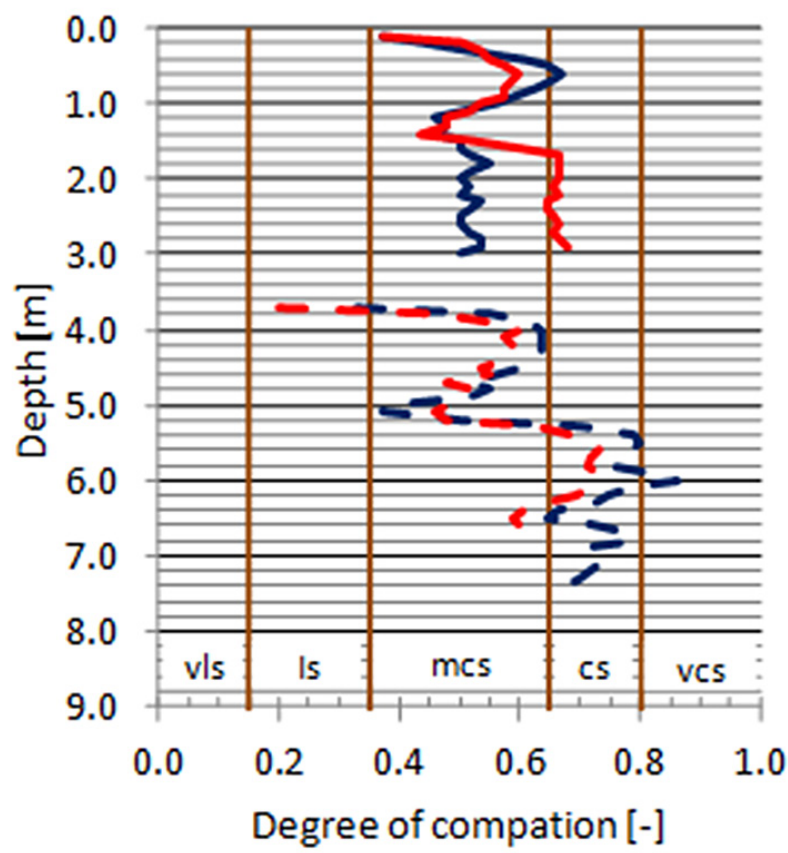

b) cross-section P2

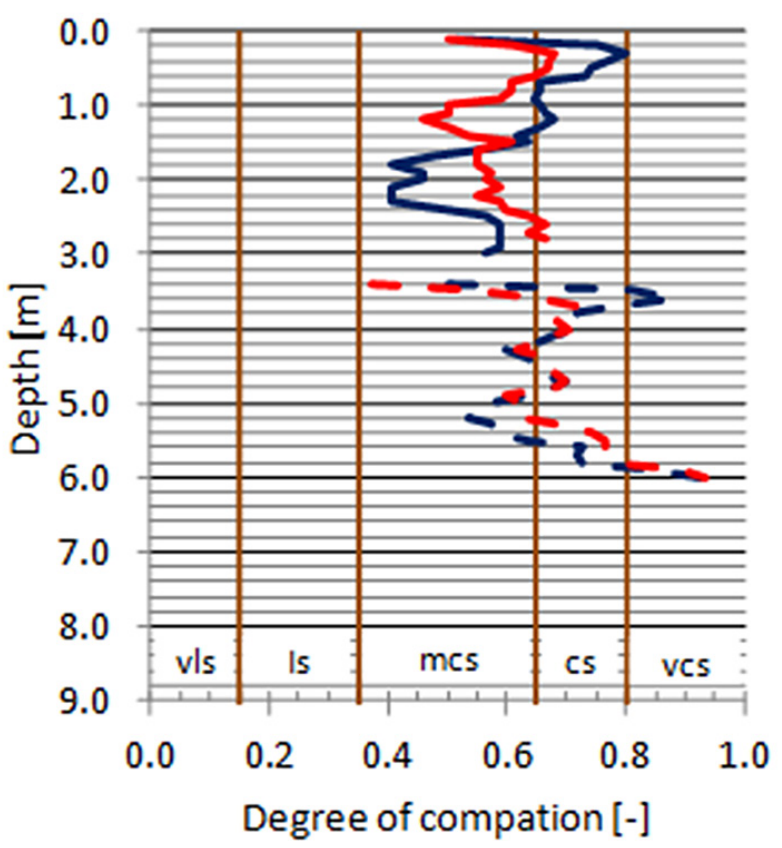

d) cross-section P4

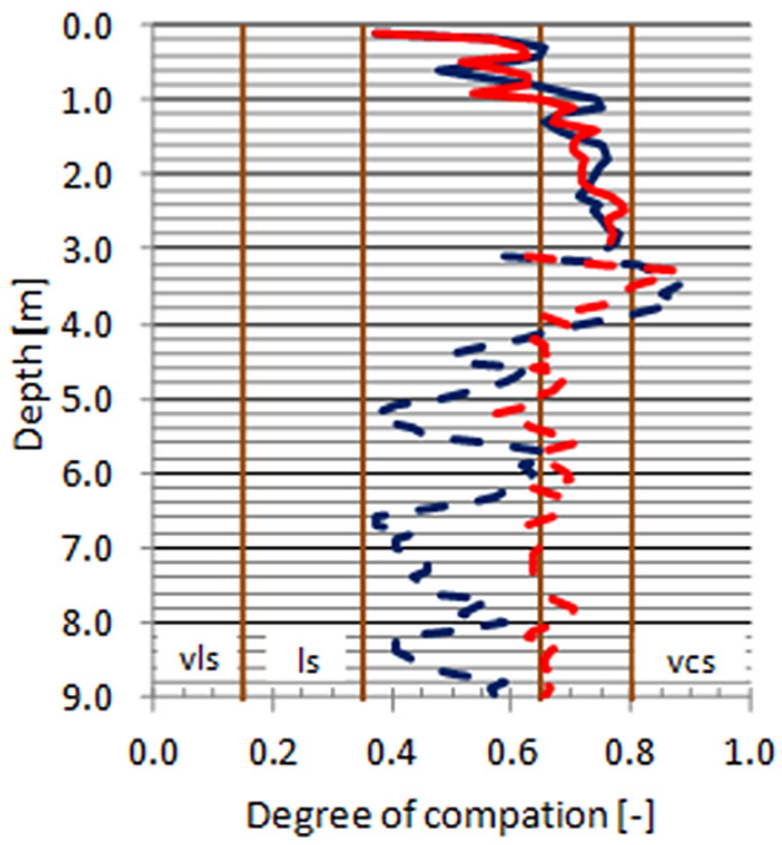

Fig. 5. Results from dynamic sounding with a cone (blue line) and vane probe (red line) from the dam's crown (solid line) and from the bed of downstream slope (dashed line) 
a) conical probe

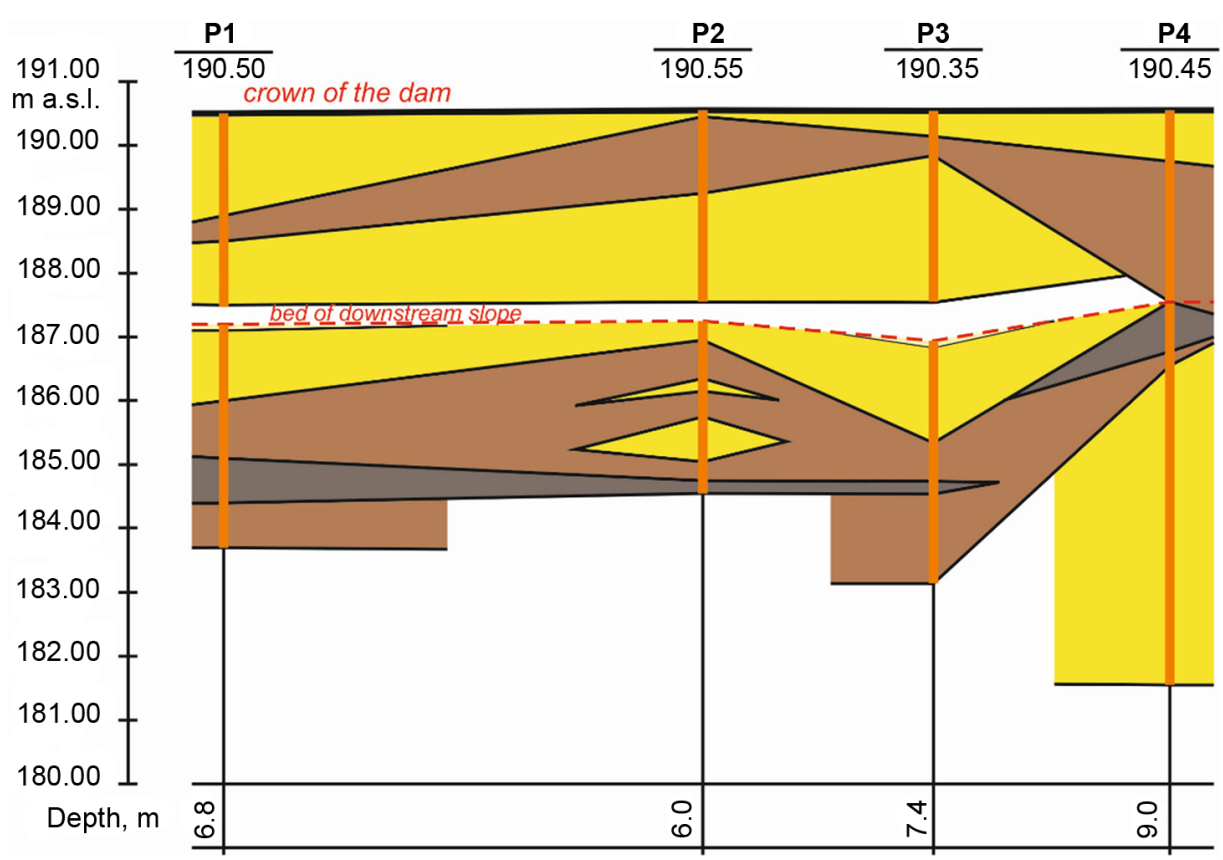

b) vane probe

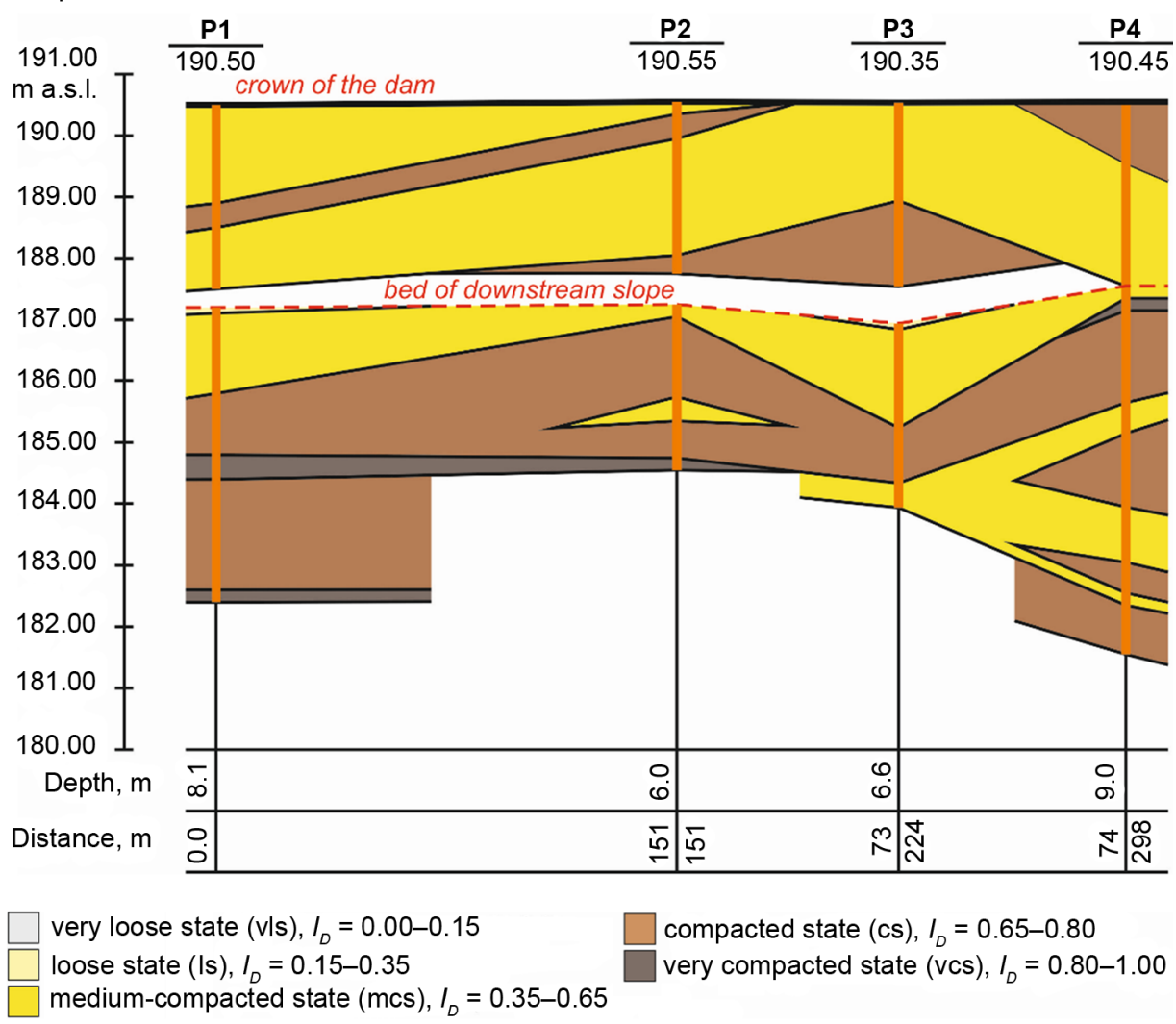

Fig. 6. Longitudinal profile of compaction state of the side dam's body 
should be considered as approximate, as they are obtained from the application of double correlation, in the first step as, and then.

Based on the values of bulk density and moisture content from the tests in the research excavations, the dry density of solid particles was estimated, which in relation to its maximum value obtained in the Proctor apparatus allowed the compaction index to be calculated in accordance with equation (4). Its values in cross-section $\mathrm{P} 1$ were from 0.84 to 0.96 , in $\mathrm{P} 2$ from 0.84 to 1.00 , in $\mathrm{P} 3$ from 0.90 to 1.02 , and in P4 from 0.86 to 0.95 .

Large range of compaction index calculated by equation (2) and the Proctor method indicates improper soil compaction of the dam's body (see: Table 2). The results are compliant with the research by Łacheta and Bednarczyk (2000, 2001), assessment of technical condition and operation of dams of 'Mazarnia' water reservoir and efficiency of corrective works. However, it should be clearly stated that the local inspection undertaken during the tests does not indicate problems with the operation of the reservoir, which is pursuant to the instructions for reservoir management (Instrukcja, 2011).

Comparing the compaction index obtained from the Proctor method - equation (4) and calculated from sounding results - equation (2), demonstrates that the Proctor method provides with smaller values. However, it should be clearly noted that in the Proctor method only the slope soil layer was tested to a depth of about 0.5 to $0.6 \mathrm{~m}$. So it was a surface zone exposed to the largest changes in density as a consequence of penetrating the soil by plant roots and freezing. On the other hand, it should be clearly indicated that assessing the state of compaction through the compaction index obtained from soundings should be approached with great caution and interpreted accordingly. The trouble with this type of interpretation of soundings follows from the fact that what is derived from sounding is the degree of compaction, not the compaction index (Kraszewski, 2017).

Table 2. Profile of basic parameters of soils in the downstream slope

\begin{tabular}{|c|c|c|c|c|c|c|c|c|c|c|c|c|c|c|c|}
\hline \multirow{4}{*}{ 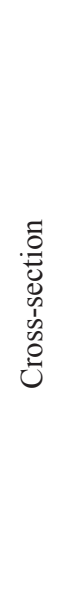 } & \multirow{4}{*}{ ज्ञ்̃ } & \multirow{4}{*}{ 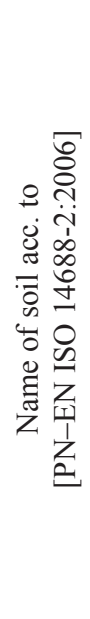 } & \multicolumn{6}{|c|}{ Field tests } & \multicolumn{7}{|c|}{ Laboratory tests - formed samples } \\
\hline & & & \multirow{3}{*}{ 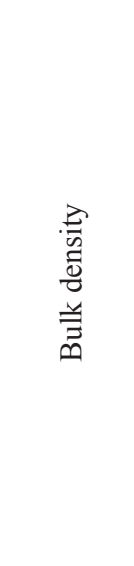 } & \multicolumn{2}{|c|}{ Compaction index [-] } & \multirow{3}{*}{ 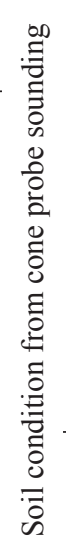 } & \multirow{2}{*}{\multicolumn{2}{|c|}{$\begin{array}{l}\text { Undrained shear } \\
\text { strength }\end{array}$}} & \multirow{3}{*}{ 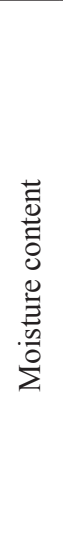 } & \multirow{3}{*}{ 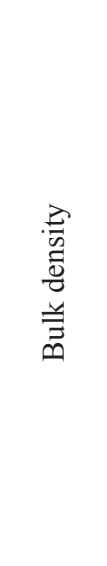 } & \multirow{3}{*}{ 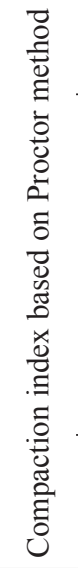 } & \multicolumn{4}{|c|}{$\begin{array}{l}\text { Parameters of shear } \\
\text { strength }\end{array}$} \\
\hline & & & & \multirow[t]{2}{*}{ 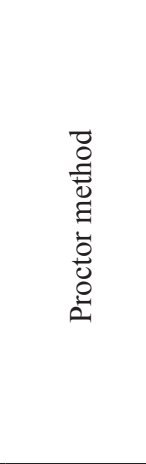 } & \multirow{2}{*}{ 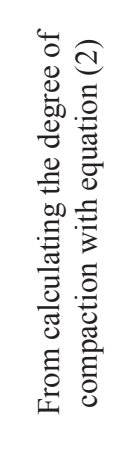 } & & & & & & & 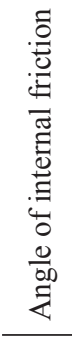 & 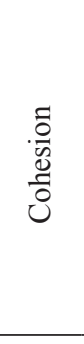 & 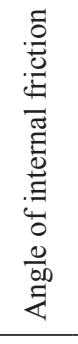 & $\begin{array}{l}\frac{\tilde{0}}{v} \\
\frac{0}{0} \\
0\end{array}$ \\
\hline & & & & & & & maximum & residual & & & & \multicolumn{2}{|c|}{$\begin{array}{l}\text { Unsaturated } \\
\text { samples }\end{array}$} & \multicolumn{2}{|c|}{$\begin{array}{c}\text { Saturated } \\
\text { samples }\end{array}$} \\
\hline- & $\mathrm{m}$ & - & $\mathrm{g} \cdot \mathrm{cm}^{-3}$ & - & - & - & \multicolumn{2}{|c|}{$\mathrm{kPa}$} & $\%$ & $\mathrm{~g} \cdot \mathrm{cm}^{-3}$ & - & $\circ$ & $\mathrm{kPa}$ & $\circ$ & $\mathrm{kPa}$ \\
\hline P1 & 2.9-3.4 & clMSa & $1.71-1.82$ & $0.86-0.92$ & $0.95-0.96$ & szg & 151.6 & 138.9 & 5.7 & 1.75 & 0.89 & 33.9 & 16.3 & 30.5 & 13.3 \\
\hline P2 & $1.0-1.5$ & $\mathrm{MSa}$ & $1.61-1.83$ & $0.84-0.95$ & $0.95-0.97$ & szg & 97.3 & 58.1 & 5.3 & 1.80 & 0.91 & 32.9 & 14.8 & 30.8 & 12.9 \\
\hline P3 & $1.2-2.4$ & clMSa & $1.90-2.12$ & $0.93-0.96$ & $0.93-0.94$ & szg & $37.9-151.6$ & $25.3-138.9$ & 4.7 & 1.75 & 0.86 & 31.6 & 15.8 & 30.6 & 13.1 \\
\hline \multirow{2}{*}{ P4 } & $1.2-1.6$ & \multirow{2}{*}{$\mathrm{MSa}$} & $1.67-1.69$ & $0.86-0.87$ & \multirow{2}{*}{$0.98-0.99$} & \multirow{2}{*}{$\mathrm{zg}$} & 136.4 & 48.0 & 6.5 & 1.70 & 0.87 & 35.7 & 17.9 & 35.5 & 14.8 \\
\hline & $2.0-3.0$ & & $1.64-1.84$ & $0.86-0.95$ & & & 151.6 & 138.9 & 6.0 & 1.75 & 0.90 & 34.5 & 14.5 & 33.1 & 12.5 \\
\hline
\end{tabular}




\section{Shear strength}

Under conditions with "drainage", shear strength is proportional to the tangent of the angle of internal friction and cohesion (Bond and Harris, 2010; Wysokiński et al., 2011; Dąbska and Gołębiewska, 2012). Under conditions " undrained", normal stresses acting on the shear plane do not affect the soil's shear strength. Total disappearance of the frictional nature of shear resistance $(\varphi=0)$ occurs when a soil is in a state of full saturation $(\mathrm{Sr}=1)$ and water drainage is impossible (Wesley 2010).

Undrained shear strength with a vane probe was taken at a depth at which the minimum or maximum number of hits from sounding with a conical probe was recorded in individual research cross-sections. Figure 7 presents changes in undrained shear strength along with the depth measured from the dam's crown.

Undrained shear strength ranged from 38 to $152 \mathrm{kPa}$, and its minimum (residual) value was between 18 and $139 \mathrm{kPa}$, which corresponded to the values of impact of the beater per $0.1 \mathrm{~m}$ of probe drive - from 8 to 32 . Residual strength was much lower, but its values were still high, indicating significant soil strength. The structural sensitivity index of the examined soils $\left(I_{R}\right)$ varied from 1.09 to 2.84, proving that these soils are insensitive to destruction of the structure (PN-B-04452: 2002).

It is important to note a significant compliance between the soil condition and the undrained shear strength value. At high values of the degree of compaction, shear strength was also high, while the range of its changes also depended on the type of soil in a given section.

Assuming in accordance with equation (1) that 4 hits of the beater correspond to the degree of compaction $I_{D}=0.35,22$ hits $-I_{D}=0.65$, and 50 hits $-I_{D}=0.80$, it can be concluded that medium-compacted soils were characterised by undrained shear strength from 38 to $136 \mathrm{kPa}$, and compacted soils from 62 to $152 \mathrm{kPa}$ (see: Fig. 8). Whereas, the residual shear strength ranged from 18 to $66 \mathrm{kPa}$ for medium compacted soils and from 38 to $139 \mathrm{kPa}$ for compacted soils.

The coefficients of determination $\left(\mathrm{R}^{2}\right)$ for the trend line in the power function indicate more adequate results of undrained shear strength in relation to the number of hits of the beater and less - in relation to the degree of compaction (see: Fig. 8). So, it can be concluded that the number of hits of the beater is a more reliable indicator and should be taken into account when selecting the depth of determination of shear strength. This is also interesting because the degree of compaction can be identified by the number of hits.

Shear strength determined in a direct shear apparatus for selected sand soil samples depended on the moisture content and bulk density at which the tests were run. To a lesser extent, this strength depended on grain size of the soils, because of their similar granulometric composition - in terms of grain size both were classified as medium or medium clay sands (PN-EN ISO 14688-2: 2006). The increase in bulk density, at which level the samples were formed, caused a slight increase in the shear strength value. Whereas water accumulation in samples led to a decrease in shear strength. It is important to point out that the extent of changes in shear strength for low values of normal stress (50 and $100 \mathrm{kPa}$ ) was small and ranged from 7 to $12 \mathrm{kPa}$ (see: Fig. 9). However, already at normal stresses of $400 \mathrm{kPa}$ changes became greater and ranged from about $31 \mathrm{kPa}$ - in the tests with sample saturation - to $44 \mathrm{kPa}$ in the tests without water accumulation. Similar relations for cohesive soils were proven by Zydroń et al. (2017).

Depending on the type of soil, as well as on moisture content and bulk density, the shear strength values had a significant impact on the shear strength parameters (see: Fig. 10). The angle of internal friction of tested sand soils, in conditions without water accumulation in samples, fluctuated in a quite narrow range, from about 32 to $36^{\circ}$ (see: Table 2). It should be noted that the soil moisture content adopted for testing was about 0.4 to 0.5 times lower than the optimum moisture content. The same was observed for cohesion, with values ranging from 15 to $18 \mathrm{kPa}$. High cohesion values for the tested sand soils are due to high resistance of grain meshing, and did not depend on intermolecular bonds formed on the surface of particles and grains.

Water saturated in samples caused an increase in moisture content of samples recorded after testing from almost 9 to nearly $13 \%$, which was almost 1.4 to 1.6 times higher than the optimum moisture 
a) cross-section $\mathrm{P} 1$

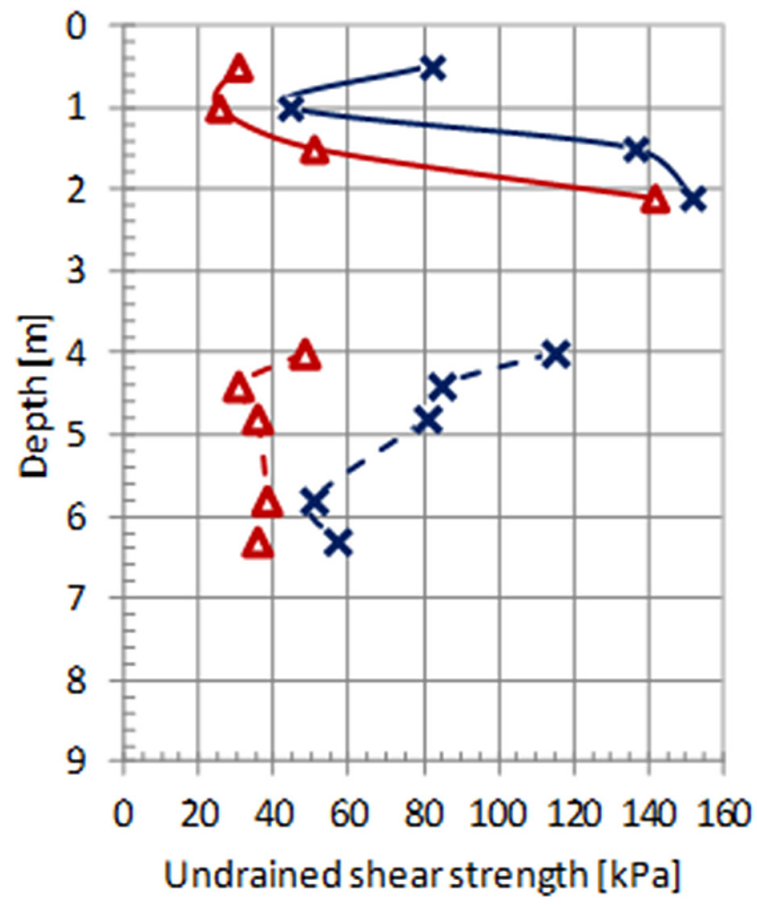

c) cross-section P3

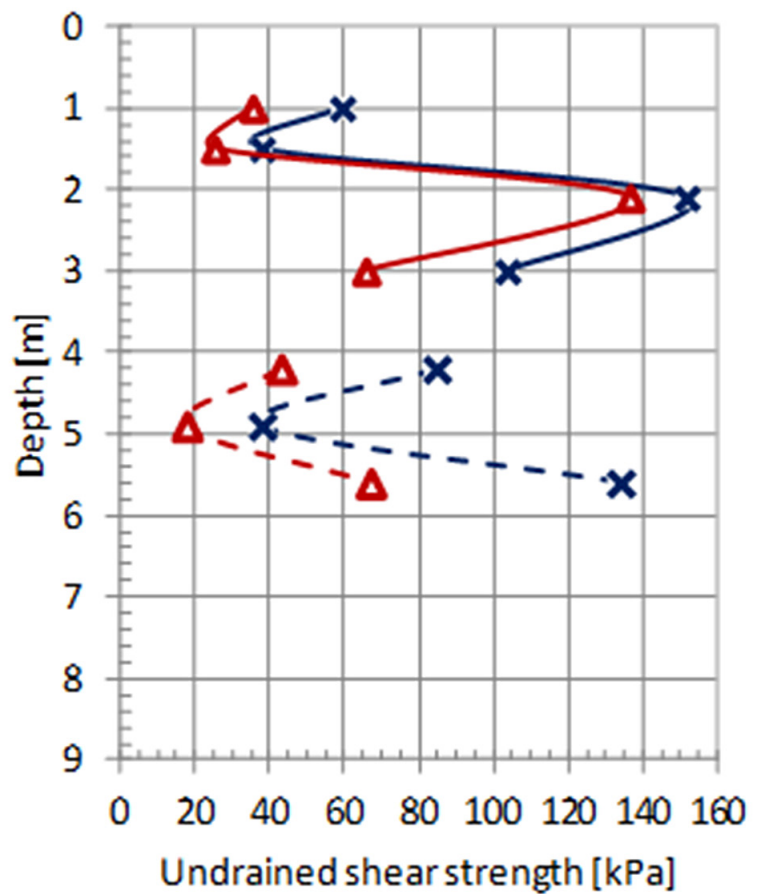

b) cross-section P2

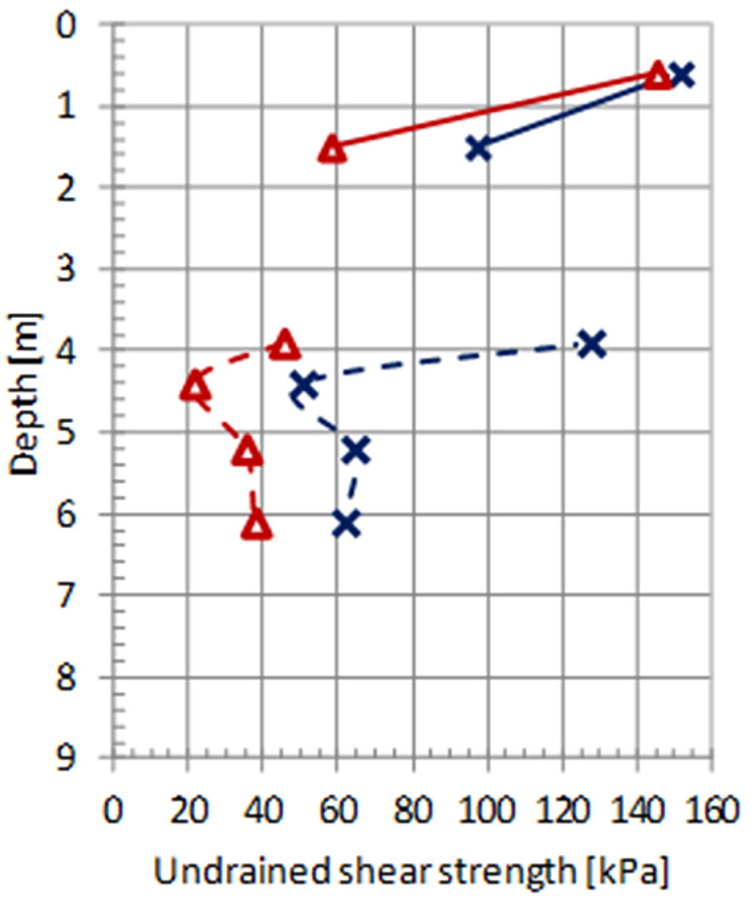

d) cross-section P4

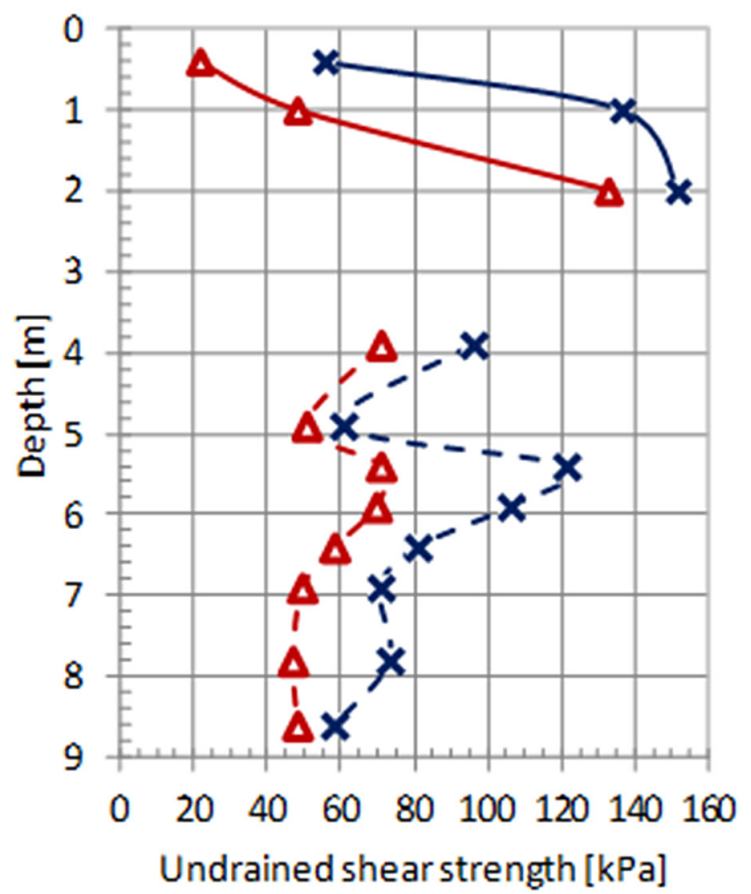

Fig. 7. Changes in maximum (blue line) and residual (red line) undrained shear strength in depth of tests from the dam's crown (solid line) and from the bed of downstream slope (dashed line) 

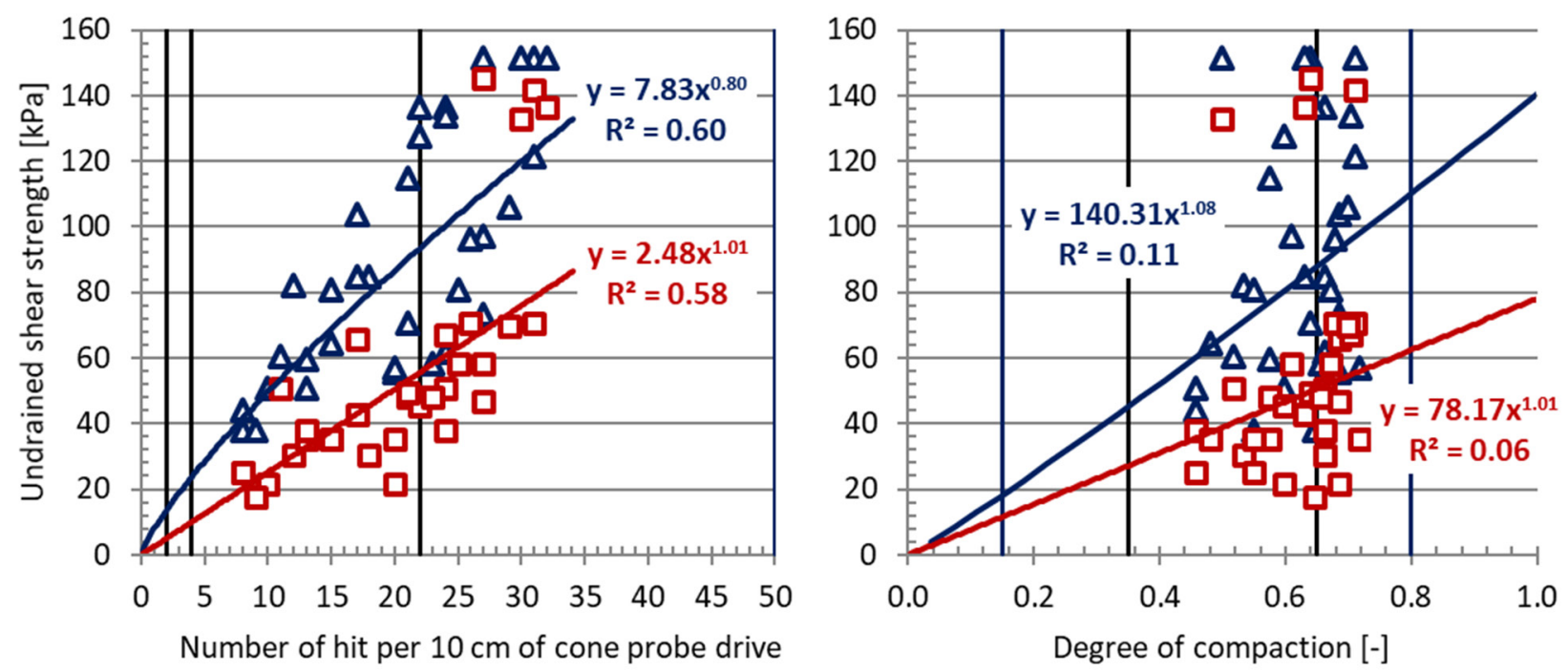

$\Delta$ maximum value $\square$ residual value

Fig. 8. Relationship between undrained shear strength and number of hits and degree of compaction

a) unasturated samples

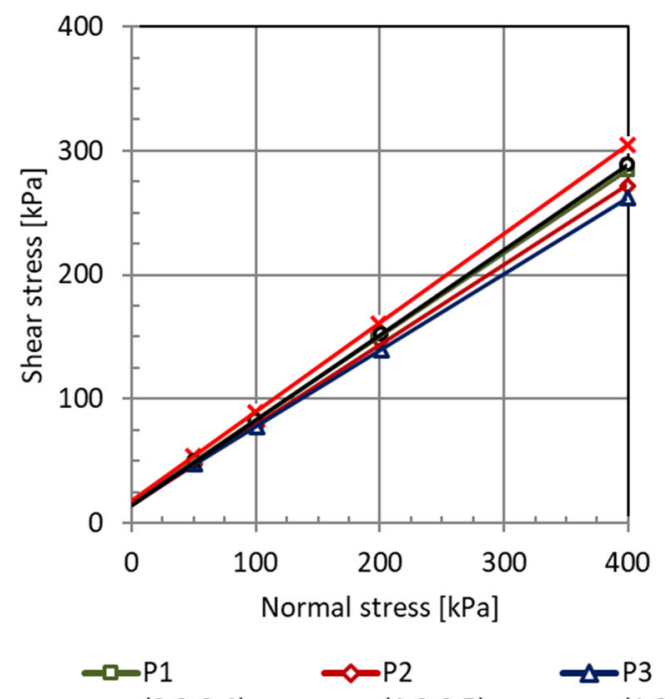

b) saturated samples

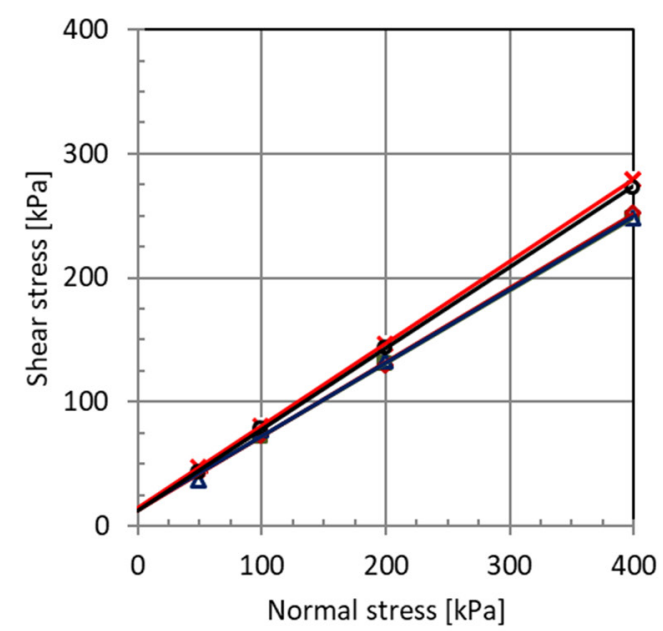

$-\mathrm{X}-\mathrm{P} 4$

$(1.2-1.6) \mathrm{m}$

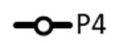

$(2.0-3.0) \mathrm{m}$

Fig. 9. Relationship between shear stress and normal stresses of soil of the dam's body 


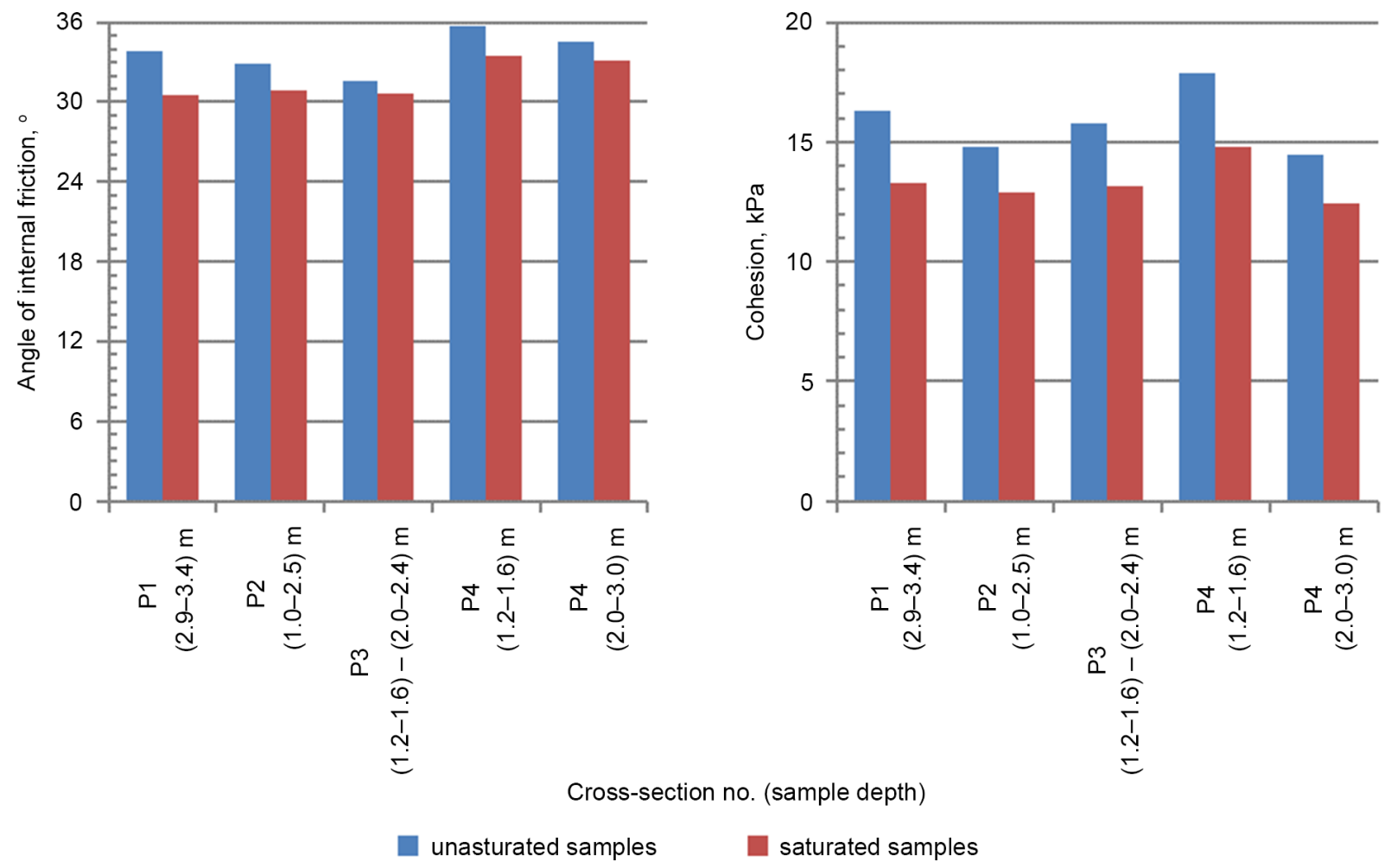

Fig. 10. Shear strength parameters of soils within the dam's body

content. The increase in moisture content caused a decrease in the angle of internal friction from 1 to nearly $3.5^{\circ}$, which was 3 to $10 \%$ of its relative value in tests without water accumulation. Similar changes were observed in the case of cohesion - the increase in moisture content induced its decrease by 2 to $3 \mathrm{kPa}$ (from 14 to $19 \%$ relative). Analysis of results indicates an increase in shear strength parameters with an increase in moisture content in tests without water accumulation and a decrease in the tests with water accumulation, although the extent of these changes was not too large. It proves that with increasing moisture content of the examined soils, to obtain the optimum moisture content, the shear strength parameters increased and, after exceeding it, decreased.

Analysis of the results of shear strength tests in field and laboratory conditions showed no clear relationships between the tested parameters. This points to significant methodological and interpretation difficulties in assessing undrained shear strength through shear strength tests with direct shear and vice versa. Assuming that normal stresses do not affect undrained shear strength, the value of cohesion should be adopted from the direct shear tests as a reliable comparison. However, this raises some reservations, because comparing cohesion and undrained shear strength it should be clearly indicated that cohesion was at least twice smaller. Analysing the obtained data, it should also be considered that the water table has not been drilled and, as a consequence, the undrained shear strength values do not refer to fully saturated soils, and therefore are overestimated. This is confirmed by laboratory tests of shear strength, where a decrease in its value was observed after the samples were saturated with water.

\section{SUMMARY}

The analysis of the geotechnical structure of the side dam's body and its density as well as strength parameters presented in the paper demonstrated quite sig- 
nificant differences. The body of the "B" side dam of the "Maziarnia" water reservoir is dominated by non-cohesive soils, with density medium-compacted, compacted and very compacted.

Sounding results prove that performing compaction control with a dynamic probe is valuable. It should be emphasised that the values of degree of compaction and index compaction estimated on the basis of correlations - differed significantly depending on the probe vane.

The compaction index obtained from tests and calculations varied widely. It was found that for the most part the soils making the side dam's body were characterized by low values of compaction index. However, the local vision does not indicate any deformations of the dam's body that could cause its loss of stability. Similarly, high values of shear strength parameters from a vane probe tests and a direct shear apparatus allow a very positive assessment of the stability of the entire object as well as its individual components such as the downstream slope.

Studies demonstrating the relationship between shear strength parameters and undrained shear strength will continue. Measuring undrained shear strength with a vane probe is an in-situ test that does not need samples extracted from a part of the dam's body. Thus, the results of these tests based on appropriate assumptions and correlations may allow assessing the stability of earth embankments.

\section{REFERENCES}

Baran, P., Cholewa, M., Klimek, M. (2016). The influence of water levels changes on the behavior of hydraulic embankments models constructed from ash-slag. Acta Sci. Pol. Formatio Circumiectus, 15(4), 41-51, DOI: https:// doi.org/10.15576/ASP.FC/2016.15.4.41.

Bond, A., Harris, A. (2010). Decoding Eurocode 7. London and New York: Taylor \& Francis Group.

Dąbska, A., Gołębiewska, A. (2012). Podstawy geotechniki. Zadania według Eurokodu 7. Warszawa: Oficyna Wydawnicza Politechniki Warszawskiej.

Dąbska, A., Pisarczyk, S. (2016). Wyznaczenie parametrów geotechnicznych stosowanych do określania jakości zagęszczenia nasypów z gruntów niespoistych. Acta Sci. Pol. Architectura, 15 (3), 3-15

Godlewski, T. (2013). Interpretacja badań polowych a Eurokod 7. Acta Sci. Pol. Architectura, 12(3), 61-72.
Gruchot, A., Zydroń, T., Zawisza, E., Bembenek, D., Szałucha, Ł. (2019). Analysis of filtration processes by earth hydrotechnical structures. Acta Sci. Pol. Formatio Circumiectus, 18(1), 39-50, DOI: http://dx.doi.org/10.15576/ ASP.FC/2019.18.1.39.

Hawrysz, M., Stróżyk, J. (2015). Kontrowersyjna interpretacja wyników sondowań dynamicznych w praktyce inżynierskiej. Inżynieria Morska i Geotechnika, 3, 203-207.

Instrukcja 2011. Instrukcja gospodarowania wodą dla zbiornika w Wilczej Woli. Rzeszów: Zakład Usług Geodezyjno-Projektowych, Marek Gamracy.

Kraszewski, C. (2017). Zagęszczanie gruntów niespoistych i kontrola zagęszczenia w budownictwie drogowym. Infrastruktura, Vademecum, 2-5.

Łacheta, S. Bednarczyk, T. (2001). Ocena stanu technicznego zapór ziemnych zbiornika „Maziarnia” w Wilczej Woli. Etap 2. Sprawdzenie skuteczności prac korekcyjnych, kontrolne pomiary pracy zapór, analiza materiałów uzyskanych z badań oraz opracowanie dokumentacji potwierdzającej sprawność zapór. Akademia Rolnicza im. H. Kołłątaja w Krakowie, Katedra Mechaniki Gruntów i Budownictwa Ziemnego (maszynopis).

Łacheta, S., Bednarczyk, T. (2000). Ocena stanu technicznego zapór ziemnych zbiornika „Maziarnia” w Wilczej Woli. Etap I. Kontrola stanu i pracy zapór oraz przedstawienie zakresu niezbędnych prac korekcyjnych. Akademia Rolnicza im. H. Kołłątaja w Krakowie, Katedra Mechaniki Gruntów i Budownictwa Ziemnego (maszynopis).

PN-B-04452:2002. Geotechnika. Badania polowe. Warszawa: Polski Komitet Normalizacyjny.

PN-B-04481:1988. Grunty budowlane. Badania próbek gruntu. Polski Komitet Normalizacji, Miar i Jakości. Warszawa: Wydawnictwo Normalizacyjne „Alfa”.

PN-EN 1997-1:2008. Eurokod 7. Projektowanie geotechniczne. Część 1. Zasady ogólne. Warszawa: Polski Komitet Normalizacyjny.

PN-EN ISO 14688-2:2006. Rozpoznanie i badania geotechniczne. Oznaczanie i klasyfikowanie gruntów. Część 2: Zasady klasyfikowania. Warszawa: Polski Komitet Normalizacyjny.

Tarnawski, M., Michalec, B. (2006). Charakterystyka ilościowa i jakościowa osadów dennych zbiornika wodnego w Wilczej Woli. Infrastruktura i Ekologia Terenów Wiejskich, 3, 31-43.

Wesley, L.D. (2010). Fundamentals of soil mechanics for sedimentary and residual soils. New Jersey: John Wiley \& Sons, Inc., Hoboken. 
Wysokiński, L., Kotlicki, W., Godlewski, T. (2011). Projektowanie geotechniczne według Eurokodu 7. Warszawa: Instytut Techniki Budowlanej.

Zydroń, T. (2016). Ocena właściwości wytrzymałościowych gruntów z wykorzystaniem analizy wstecznej na przykładzie jednego z osuwisk na zboczu Wiatrówki (Beskid Niski). Acta Sci. Pol. Formatio Circumiectus,
15(1), 139-150, DOI: http://dx.doi.org/10.15576/ASP. FC/2016.15.1.139.

Zydroń, T., Wojciechowska-Dymańska, M., Gruchot, A., Zaleski, T. (2017). Wpływ wilgotności na wytrzymałość na ścinanie wybranych gruntów spoistych. Przegląd Komunikacyjny, 77, 5, 9-14.

\section{OCENA ZAGĘSZCZENIA I WYTRZYMAŁOŚCI NA ŚCINANIE GRUNTÓW KORPUSU ZAPORY BOCZNEJ ZBIORNIKA WODNEGO „MAZIARNIA”}

\section{ABSTRAKT}

\section{Cel pracy}

Celem pracy była ocena zagęszczenia gruntów korpusu bocznej zapory ziemnej „B” zbiornika wodnego „Maziarnia” w Wilczej Woli w województwie podkarpackim z wykorzystaniem końcówki stożkowej i krzyżakowej lekkiej sondy dynamicznej. Oznaczono również parametry wytrzymałości na ścinanie gruntów wbudowanych w korpus zapory, a więc wytrzymałości na ścinanie bez odpływu na podstawie badań polowych oraz kąta tarcia wewnętrznego i spójności w aparacie bezpośredniego ścinania.

\section{Materiał i metody}

Badania terenowe obejmowały oznaczenie gęstości objętościowej gruntu oraz sondowanie lekką sondą dynamiczną wraz z oznaczeniem wytrzymałości na ścinanie bez odpływu w czterech przekrojach zlokalizowanych na skarpie odpowietrznej na odcinku o długości około $300 \mathrm{~m}$. Zakres badania laboratoryjnych dotyczył oznaczenia składu uziarnienia, parametrów zagęszczalności w aparacie Proctora. Oznaczono także parametry wytrzymałości na ścinanie, a więc kąta tarcia wewnętrznego i spójność w aparacie bezpośredniego ścinania na próbkach bez i z zawodnieniem w trakcie konsolidacji i ścinania.

\section{Wyniki i wnioski}

Uzyskane wyniki i ich analiza wskazują, że wartość oszacowanego na podstawie zależności korelacyjnych stopnia zagęszczenia i wskaźnika zagęszczenia w zależności od zastosowanej końcówki sondy różniła się znacząco. Stwierdzono, że w dużej części grunty budujące korpus zapory bocznej cechowały się niskimi wartościami wskaźnika zagęszczenia. Wysokie wartości parametrów wytrzymałości na ścinanie tak z badań sondą krzyżakową i z aparatu bezpośredniego ścinania pozwalają jednak wysoko ocenić stateczność całego obiektu. Na podstawie przeprowadzonej analizy wyników badań wytrzymałości na ścinanie w warunkach polowych i laboratoryjnych nie stwierdzono jednoznacznych zależności pomiędzy badanymi parametrami.

Słowa kluczowe: spójność, kąt tarcia wewnętrznego, lekka sonda dynamiczna, wytrzymałość na ścinanie bez odpływu 